\title{
Typology Of Cattle Herds In Transhumance In The Classified Forest Of Upper Alibori Northern Benin
}

\author{
Alassan Assani Seidou \\ Ibrahim Alkoiret Traore \\ Laboratory of Ecology, Health and Animal Production (LEHAP), \\ Faculty of Agronomy (FA), University of Parakou (UP), Benin Republic

\section{Marcel Houinato} \\ Laboratory of Applied Ecology (LAE), Faculty of Agricultural Sciences \\ (FAS), University of Abomey-Calavi (UAC), Benin Republic

\section{Guy Apollinaire Mensah} \\ National Institute of Agricultural Research of Benin (INRAB), \\ Cotonou, Benin Republic
}

\section{doi: 10.19044/esj.2016.v12n15p251 URL:http://dx.doi.org/10.19044/esj.2016.v12n15p251}

\begin{abstract}
To characterize the cattle herds in transhumance in the classified forest of upper Alibori (CFUA) north of Benin, an investigation of 132 cattle herds with a total of 11,020 head was carried out. Using the methods of factorial analysis of multiple correspondences (FAMC) and ascending hierarchical classification (AHC), a typology of four types of transhumant cattle herds were established. Cattle herds of type 1 (17.5\% of the sample) were riparian of CFUA. They were led by young herdsmen (17 \pm 3 years), all parents of herds' managers to whom they use to make all decisions concerning these herds whose average size is low ( $44 \pm 20$ head). Type 2 cattle herds (28.8\% of the sample) were from the neighboring commons of CFUA and were led by two relatively young herdsmen (26 \pm 3 years) and mostly parents of herds' managers with which they conferred to make decisions. These herds had an average size of $94 \pm 20$ head. The third type (43.9\% of the sample) consisted of transhumant herds from distant commons, passing through the CFUA towards other protected areas. They had a high size (112 \pm 13 head) and were conducted by two relatively young herdsmen (31 \pm 4 years) and mostly parents of herds' managers. Decisions were taken by the herds' managers sometimes in consultation with the herdsmen. The migratory herds of type $4(9.8 \%$ of the sample) from neighboring countries. They went through the CFUA towards protected areas further south with a very high size $(144 \pm 15$ head). These herds were conducted generally by two or three herdsmen whose average age was $36 \pm 4$
\end{abstract}


years and were heavily involved in decision making in consultation with the herds' managers. The typology implementation will allow us to analyze the different transhumance management modes in the CFUA.

Keywords: Benin, cattle herd, protected area, transhumance, typology

\section{Introduction:}

Livestock is a socio-economic activity of major importance in the world, particularly in Africa south of the Sahara. It provides both macroeconomic and environmental functions (Sawadogo, 2011). In Benin, livestock is the second resource in the primary sector, participating up to $44 \%$ of agricultural GDP (MAEP, 2011). It also contributes for $5.9 \%$ to the national GDP and proves to be a source of income for over $70 \%$ of the workforce and the first form of capitalization to almost all rural households and even urban (FAO, 2009).

The national herd, numerically large and diverse amounted in 2013 2.116 million head (FAOSTAT, 2015) for the only bovine species. This stock is more than $85 \%$ concentrated in the northern departments of the country (Alkoiret et al., 2011), where are also located most of the protected areas of Benin (Lesse et al., 2011). The rearing system is characterized by transhumance with a food system of pastoral kind, based on the exclusive use of rangelands. Transhumance is increasingly oriented towards protected areas to escape the scarcity of grazing areas, land transhumance corridors, the unsuitability of land legislation and the many social conflicts (Lesse et al., 2011).

The classified forest of upper Alibori (CFUA) is a protected area of northern Benin. It was created to protect the watershed of the Alibori River and its tributaries and to conserve biological diversity. But today it is one of the favorite destinations of national and foreign transhumance. Indeed, high animal concentrations are recorded there, causing pollution to biodiversity and many conflicts between pastoralists and farmers. One can question the capabilities of the classified forest sustainably support this level of control. To address this concern, it is necessary to make a diagnosis on the impact of the presence of bovine herds within the CFUA. The typology of cattle herds in transhumance in this protected area is the starting point of this diagnosis.

Given the extreme diversity of situations to describe, typologies have the ambition to be a set of classes that simplifies reality while respecting the main features (Perrot and Landais, 1993). The farms typologies used to compare groups of farms between them, to judge their operation, to identify possible solutions to problems and develop appropriate recommendations (Capillon, 1985). The objective of the typologies is to provide for the use of 
an image-makers of local farming to guide development actions (Roybin, 1987).

This study aims to establish through surveys in the CFUA, a typology of cattle herds in attending the transhumance.

\section{Material and methods \\ Study area}

The classified forest of upper Alibori (CFUA) was created by Decree No. 6459 of August 20, 1955. It covers an area of 250,205.73 hectares and forms a vast area covering six commons (Pehunco, Keru, Banikoara Gogunu, Sinende and Kandi) and straddling the departments of Atacora, Donga, Borgu and Alibori (Figure 1). According to the vegetation map of the forest, this forest presents five strata: woodland, gallery forest, tree and shrub savannah, savannah with agricultural presence and mosaic of crops and fallow. The climate of the area is tropical with two seasons observable during the year: a dry season from November to March and rainy season from April to October. Rainfall is unevenly distributed in time and space with water depths ranging from $900 \mathrm{~mm}$ in June to a high of $1316.5 \mathrm{~mm}$ in July and August (PGFTR, 2010).

\section{Methodology}

The survey method used was developed by the Institute of Animal Husbandry and Veterinary Medicine in Tropical Countries. It was used for the typology of cattle farming systems in many tropical countries, including Guinea (Lhoste et al., 1993), Reunion (Tache, 2001), the Philippines (Duval, 2001), the Brazil (Lau et al., 2001), Morocco (Sraïri, 2004) and Benin (Alkoiret et al, 2009, 2011; Assani and Alkoiret, 2014).

The transhumant cattle herds were located in each of the nine sections of the CFUA by guides in the profession of herdsman. The herdsmen of migratory herds are then addressed for consent to participate in the survey. Thus, a sample of 132 cattle herds with a total of 11020 head was formed. The surveys were conducted using an interview guide from January to May 2014 and the semi-structured interview technique was adopted.

The questions concerned the herder (Nationality, section of CFUA frequented by transhumant, proximity of the original camp, number and age of herdsmen, relationship between herd manager and herdsmen, mode of decision making), the animals (cattle numbers, breeds of animals and acquisition mode of the herd) and the practices of transhumance (input section in CFUA, final destination, period and reasons of entry into CFUA, frequency of use of protected areas, watering places). 


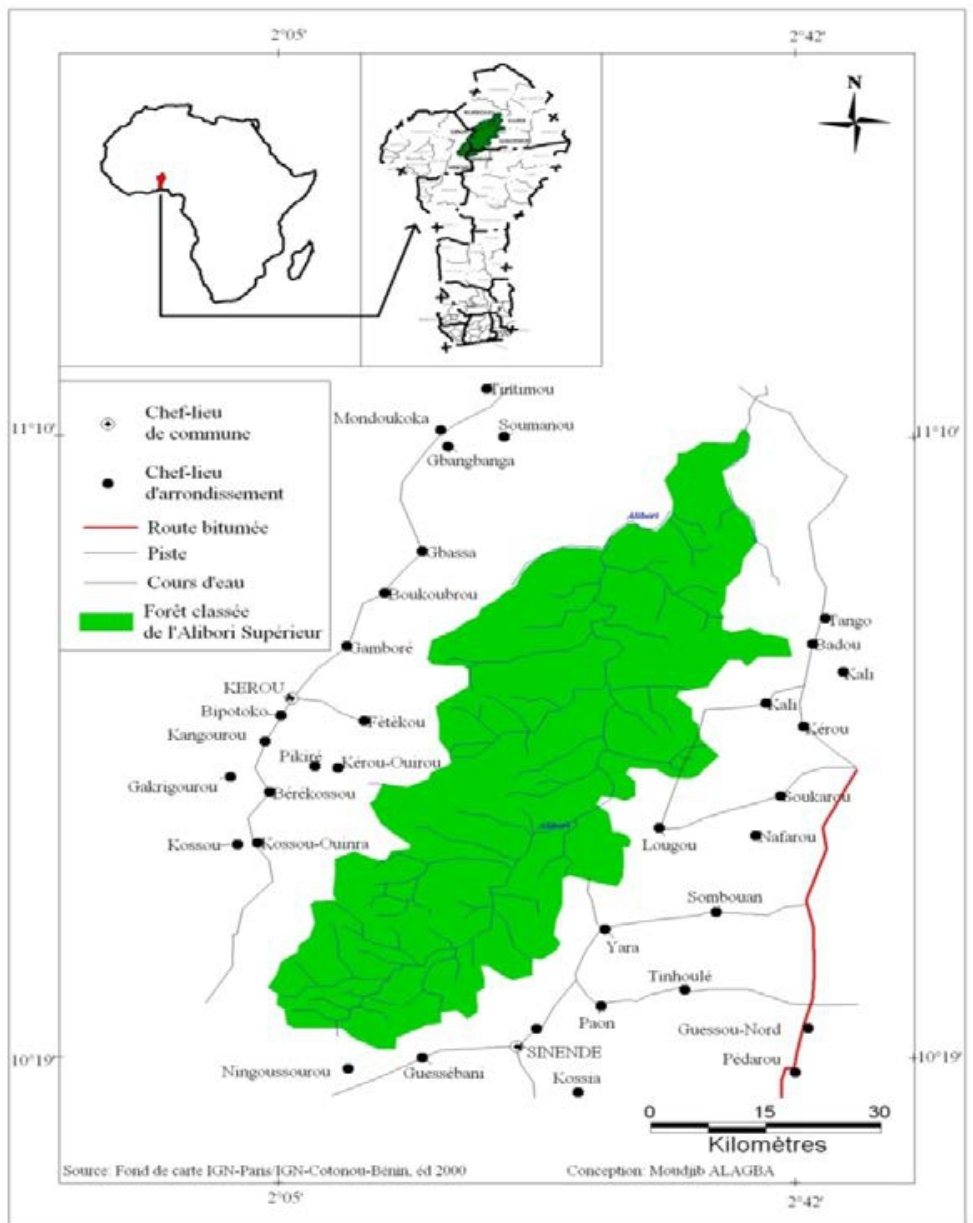

Figure 1. Location of the classified forest of upper Alibori

The transhumant herds were under the responsibility of herds' managers which the owners of the animals entrusted them. Herds' managers were taking major decisions (starting transhumance, vaccination, deworming, purchase of medicines and salt). They also resolved conflicts caused by animals and affected the costs to owners. Herdsmen engaged in implementing the grazing circuit, monitoring of animals, parking, watering and milking. In exchange for this work, they enjoyed the milk and remuneration in cash or livestock head per season.

\section{Data analysis}

Analysis of the survey data was performed using the software R.2.15.2® in two steps:

- A Factorial Analysis of Multiple Correspondence (FAMC), which has produced a representation of the farms in the form of projections on the planes defined by the first factorial axes (Escofier and Pages, 1990). 
- An Ascending Hierarchical Classification (AHC) classification method (from the holdings of the coordinates on the main factor axes), which lets you group farms according to their proximity to each other. All individuals is represented as a tree (dendrogram) and different typology groups correspond to the main "branches" of the tree (Bourzat, 1986).

\section{Results}

\section{Development of the typology}

Correlations between the variables allowed to retain a set of 15 active variables giving 45 terms. The analysis of coordinated major projection axes of the MCA is summarized in Table 1. The cumulative contribution to the total inertia of the first three factorial axes retained was approximately $73.0 \%$ (Table 2).

Table 1. Definition of factorial axes

\begin{tabular}{|c|c|c|}
\hline axes & Negative & Positive \\
\hline \multirow[t]{7}{*}{1} & Herdsmen rather older & Herdsmen rather young \\
\hline & high number of cattle & Low number of cattle \\
\hline & Permanent use of CFUA & Occasional use of CFUA \\
\hline & Lack of forage and water & Lack of forage \\
\hline & Transit through CFUA & CFUA final destination \\
\hline & Foreign Breeders & National Breeders \\
\hline & Herdsmen parents and employee & Herdsmen parents of herd manager \\
\hline \multirow[t]{2}{*}{2} & Purebred Zebu & Crossbreed Borgu * Zebu \\
\hline & Non riparian of CFUA & Riparian of CFUA \\
\hline \multirow[t]{2}{*}{3} & $\begin{array}{l}\text { Decisions by herd manager and } \\
\text { herdsmen }\end{array}$ & Decisions by herd manager alone \\
\hline & $\begin{array}{l}\text { Herd formed by purchase, inheritance } \\
\text { and fostering }\end{array}$ & $\begin{array}{l}\text { Herd formed by purchase and } \\
\text { inheritance }\end{array}$ \\
\hline
\end{tabular}

\section{Defining Groups}

To further define the types of cattle herds in transhumance in the CFUA from the review of the FAMC, a CAH was carried out with all the data. This analysis allowed to distinguish four types of cattle herds in transhumance inside this forest. The frequencies of the different terms of the variables related to the 4 types of cattle herds identified were given in Tables 2 and 3.

Table 2. Cumulative contribution to the total inertia of the factorial axes

\begin{tabular}{lll}
\hline Factorial axes & \% Inertia & \% Cumulative \\
\hline 1 & 43.8 & 43.8 \\
2 & 18.1 & 61.9 \\
3 & 11.1 & 73.0 \\
\hline
\end{tabular}


The best graphical representation was provided by a projection in a plane defined by the factorial axes 1 and 2 (Figure 2). The general characteristics were:

\section{Type 1 ( 23 herds or $17.5 \%$ of the sample):}

Herds of this type were present in all sections of CFUA. Breeders are Beninese and their original settlements were located along the CFUA. The herdsmen all had family ties with the herds' managers and their average age was $17 \pm 3$ years. They were often one or two people per herd. In this type, most decisions were taken by the herds' managers.

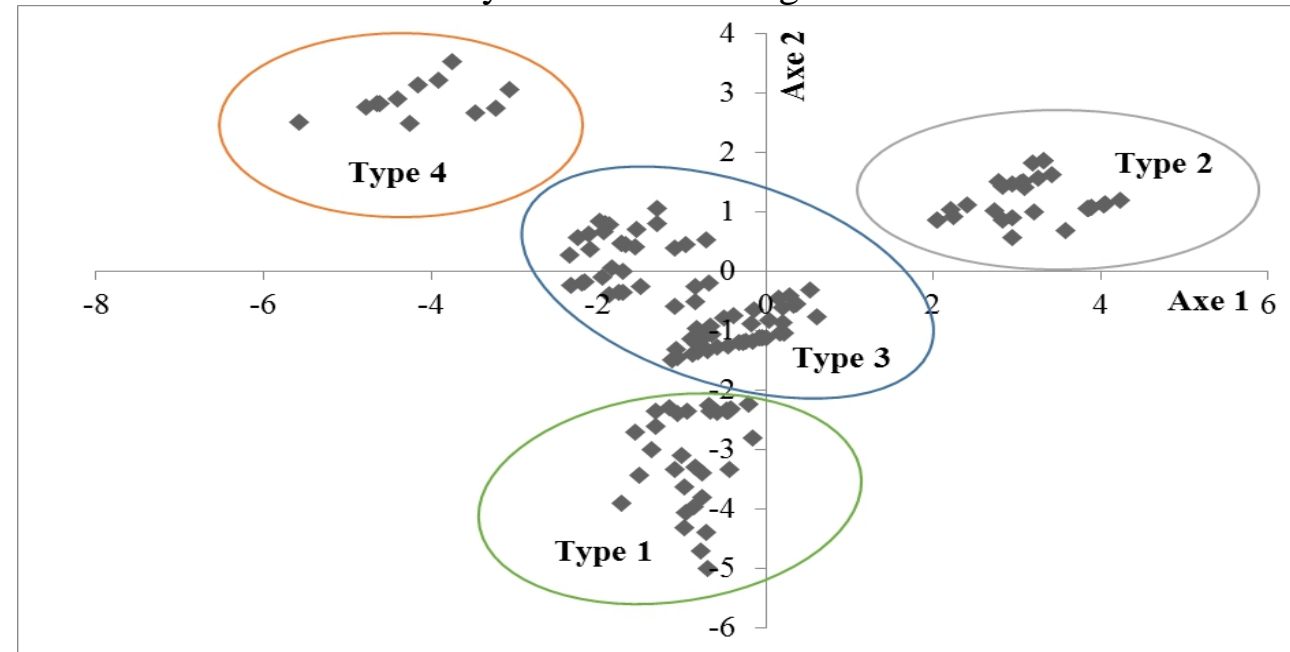

Figure 2. Projection of cattle herds surveyed on the factorial axes 1 and 2.

The average size of such cattle herds was $44 \pm 20$ head and animals were purebred Borgu and crossbreed Borgu * Zebu. These herds were essentially established by inheritance and spent all seasons of the year within the CFUA. The lack of forages was the main reason for entering the CFUA used them constantly grazing area. Watering of type 1 herds was provided by rivers and dams built around the CFUA.

\section{Type 2 (38 herds or $28.8 \%$ of the sample)}

Cattle herds of type 2 were led by Beninese breeders residing in riparian Commons North (Gogunu and Kandi) and south (Sinende and Pehunco) of CFUA and they went on transhumance in the forest sections contiguous to their commons. These herds were led by two herdsmen with an average age of $26 \pm 3$ years and for most parents of the herds' managers. The mode of decision making adopted by the breeders of this type was college involving the herds' managers and the herdsmen. 
Table 3. Frequency (\%) of the terms describing the breeder as cattle herd types identified

\begin{tabular}{|c|c|c|c|c|c|}
\hline Variables & Terms & Type 1 & Type 2 & Type 3 & Type 4 \\
\hline NAB $=$ Nationality & Beninese & 100 & 100 & 100 & 0 \\
\hline of breeder & Foreign & 0 & 0 & 0 & 100 \\
\hline SFT $=$ Section of & Bagu & 22.9 & 0 & 4.2 & 23.1 \\
\hline CFUA frequented by & Lugu & 12.5 & 30.4 & 8.3 & 0 \\
\hline \multirow[t]{7}{*}{ Transhumant } & Sam & 6.3 & 30.4 & 4.2 & 7.3 \\
\hline & Gbassa & 8.3 & 4.3 & 8.3 & 7.7 \\
\hline & Feteku & 10.4 & 0 & 10.4 & 23.5 \\
\hline & Pikire & 8.3 & 0 & 16.7 & 7.7 \\
\hline & Gnemasson & 12.5 & 13 & 2.1 & 7.7 \\
\hline & Niaro & 8.3 & 13 & 18.8 & 15.4 \\
\hline & Sekere & 10.4 & 8.7 & 27.1 & 7.7 \\
\hline \multirow{5}{*}{$\begin{array}{l}\text { POC = Proximity of } \\
\text { the Original Camp } \\
\text { NUH = Number of } \\
\text { herdsmen }\end{array}$} & Riparian & 100 & 100 & 43.5 & 0 \\
\hline & Non riparian & 0 & 0 & 56.5 & 100 \\
\hline & $\mathrm{NUH}=01$ herdsman & 43.8 & 0 & 0 & 0 \\
\hline & NUH $=02$ herdsmen & 56.3 & 100 & 100 & 76.9 \\
\hline & NUH $>02$ herdsmen & 0 & 0 & 0 & 23.1 \\
\hline $\mathrm{AGE}=$ Age & AGE $<15$ years & 66.7 & 8.7 & 0 & 0 \\
\hline \multirow{2}{*}{ herdsmen } & $15<$ AGE $<30$ years & 33.3 & 91.3 & 62 & 56.5 \\
\hline & $\mathrm{AGE} \geq 30$ years & 0 & 0 & 38 & 43.5 \\
\hline \multirow{3}{*}{$\begin{array}{l}\text { RHL = Relationship } \\
\text { between herd mana- } \\
\text { ger and herdsmen }\end{array}$} & Parents & 100 & 87 & 75 & 0 \\
\hline & Employees & 0 & 13 & 18.8 & 0 \\
\hline & Parents + employees & 0 & 0 & 6.3 & 100 \\
\hline MDM $=$ Mode of & Herdsmen & 8.3 & 17.4 & 8.3 & 0 \\
\hline \multirow[t]{2}{*}{ Decision making } & Herd manager & 81.3 & 13 & 37.5 & 0 \\
\hline & Herd manager+herdsmen & 10.4 & 69.6 & 54.2 & 100 \\
\hline
\end{tabular}

The animals were predominantly crossbreed Borgu * Zebu with an average size of $94 \pm 20$ head of cattle. These herds were formed mainly by inheritance, purchase and fostering and in transit in the CFUA towards other protected areas further south. The predominant attendance period is the dry season. However, some breeders like this back in the rainy season after the installation of the cultures. The lack of fodder and water were the main reasons for entry in the CFUA and watering the animals was provided by dams.

\section{Type 3 (58 herds or $43.9 \%$ of the sample)}

The type 3 bovine herds are conducted by Beninese breeders mostly non-riparian of CFUA. They came from the commons of Malancity and Karimama north of CFUA and from the commons of Segbana and Kalale east of CFUA. 
Table 1 : Frequency (\%) of the terms describing the cattle herds surveyed for different types identified

\begin{tabular}{|c|c|c|c|c|c|}
\hline Variables & Terms & Type 1 & Type 2 & Type 3 & Type 4 \\
\hline BRA $=$ Breeds & Borgu & 43.8 & 4.3 & 0 & 0 \\
\hline of Animals & Crossbreed Borgu*Zebu & 56.8 & 95.7 & 79.2 & 0 \\
\hline & Zebu & 0 & 0 & 20.8 & 100 \\
\hline NUF $=$ Number & NUF $\leq 50$ head & 75 & 0 & 0 & 0 \\
\hline of cattle & $50<\mathrm{NUF} \leq 100$ head & 25 & 69.6 & 12.5 & 0 \\
\hline & NUF $>100$ head & 0 & 30.4 & 87.5 & 100 \\
\hline $\mathrm{HCM}=$ Herd & Inheritance & 58.3 & 17.4 & 72.9 & 30.8 \\
\hline Constitution & Inheritance and purchase & 25 & 34.8 & 25 & 69.2 \\
\hline Mode & $\begin{array}{l}\text { Inheritance, purchase \& } \\
\text { fostering }\end{array}$ & 16.7 & 47.8 & 2.1 & 0 \\
\hline FDE $=$ Final & CFUA & 83.3 & 17.4 & 16.7 & 0 \\
\hline Destination & Other protected areas & 16.7 & 82.6 & 83.3 & 100 \\
\hline PEC $=$ Period & Dry season & 0 & 43.8 & 91.3 & 100 \\
\hline $\begin{array}{l}\text { of Entry into } \\
\text { CFUA }\end{array}$ & Dry season and rainy season & 100 & 56.3 & 8.7 & 0 \\
\hline REC $=$ Reasons & Forages & 72.9 & 4.3 & 8.3 & 0 \\
\hline of Entry into & Water & 0 & 8.7 & 20.8 & 61.5 \\
\hline CFUA & Forages and water & 27.1 & 87 & 70.8 & 38.5 \\
\hline WAP = watering & Rivers & 0 & 21.7 & 14.6 & 0 \\
\hline Places & Dam & 0 & 47.8 & 10.4 & 0 \\
\hline & Rivers and dam & 100 & 30.4 & 75 & 100 \\
\hline FUP= & Always & 100 & 65.4 & 100 & 100 \\
\hline $\begin{array}{l}\text { Frequency of } \\
\text { use of CFUA }\end{array}$ & Occasionally & 0 & 34.6 & 0 & 0 \\
\hline
\end{tabular}

These herds were found in all sections of the CFUA led by two herdsmen with a mean age of $31 \pm 4$ years and for most parents of heads' managers. The decisions regarding the conduct of animals were taken either by the herd manager only, or in consultation with the herdsmen.

Herds of this type had a relatively high size (112 \pm 13 head) and were formed essentially by inheritance. The herds were composed of females crossbreed Borgu * Zebu and Zebu bulls (breeds M'Bororo, Gudali and Azawack). Breeders leading these types of herds had always declared to have recourse to the protected areas to meet the food needs (forage and water) mainly during the dry season. The length of stay varies from a few days to 3 months depending on available food resources. The classified forest of Higher Alibori is for them a transition area because their final destination is farther south in the reserved forests of the Upper Weme, Wenu-Benu, Warimaro and Kouffe Mountains in the center of country.

\section{Type 4 (13 herds or $9.8 \%$ of sample)}

The migratory herds of this type were conducted by breeders from Niger and Burkina Faso, therefore outsiders. They were entering the CFUA 
by sections of Gbassa, Sam, Feteku and Pikire from trans-boundary reserve of W that spans three countries: Benin, Burkina Faso and Niger. These herds were conducted generally by two or three herdsmen whose average age was $36 \pm 4$ years and were heavily involved in decision making in consultation with the herds' managers.

These herds had high size (144 \pm 15 heads) and were formed mainly through inheritance and purchase. The animals were all zebu breeds (M'bororo, Gudali, Azawack and Djelli). In search of fodder and water to meet the needs of their animals, cross-border transhumant crossing the CFUA at the beginning of the dry season in the direction of grazing areas located in southern Benin and Togo. They did reverse course early in the rainy season to their countries of origin.

\section{Discussions}

The transhumant livestock system is increasingly dependent on protected areas. This same observation was made in the west of Burkina Faso by Kiema and Fournier (2007) in the biosphere reserve of the Hippopotamus pool and classified forests of Maro and Tuy.

The migratory herds encountered in CFUA can be classified into two categories: national transhumant (Types 1,2 and 3) and cross-border transhumant (Type 4). These two forms of transhumance (national and crossborder) have been observed in the Biosphere Reserve of Pendjari northwest of Benin (Houinato and Sinsin, 2000). Transhumant type 1 live in camps in borders of CFUA. Their animals go inside the CFUA each day to graze and return to camp for the night. This type of transhumance (Type 1) was once reported by Kperou Gado (2006) in the riparian zone of the Park W in Benin. Transhumant type 2 live in neighboring commons of CFUA, but their camps are farther from the CFUA. They frequent the CFUA during the rainy season, after the installation of crops (to avoid conflicts with farmers) and during the dry season, when food resources are declining around their camps. Transhumant type 3 from more distant commons north and west of the country. They go through the CFUA way to grazing areas located in central Benin. National transhumant (Types 1,2 and 3) follow the rangers' movements in and out of the protected area. They return after a large forest patrol and monitor the points already monitored by them. On transhumance places women care of the household and the sale of milk while men engaged in animal feed and sometimes the sale of animals in livestock markets. Regarding cross-border transhumance (Type 4), it is a practice of nomadic herders from neighboring countries (Burkina Faso and Niger) that pass through the CFUA to other protected areas south of Benin and Togo.

In its work on possibilities of reception of Sahelian breeders in the commons of Malancity, Kandi and Gogunu in northern Benin, Adjagnissode 
(2003) identified two types of nomadic herders attending protected areas of North Benin: Indigenous and allochthonous. Indigenous herders remain in the village lands home or host from which they depart every morning in protected areas to feed and water their herds. As for allochthonous herders, they have no local home or home soil. They settled instead directly in protected areas and make maximum use of forage resources of each site selected. Both types of transhumance, according to the same author, operate air pastures, except that the impact of allochthonous herders camped directly in protected areas is higher than that of natives.

According to Sounkere (2003), cross-border transhumance is distinguished by the fact that it brings with it a higher number of animals than the average recorded in the national breeders. So Houinato (2001) found an effective at least 100 head of cattle per herd of this kind in Kouffe Mountains in central Benin and Sogbohossou (2000) found an effective of around 107 cattle in the hunting area of Pendjari northwest of Benin.

\section{Conclusion}

This study identified four types of cattle herds performing transhumance within the classified forest of upper Alibori (CFUA). These types of cattle herds are differentiated by the nationality of herders, the proximity of the original camps, the number and age of herdsmen, the number of cattle per herd, the times and entry reasons in the CFUA and the transhumance practices adopted.

This typology will be used to analyze the different transhumance management modes in CFUA, in order to achieve sustainable exploitation system of pastoral resources of this protected area, which can allow to reconcile biodiversity conservation actions and livestock activities.

\section{Acknowledgments}

The authors thank the International Foundation for Science (IFS) for funding this study by the grant D/5824-1. They also expressed their acknowledgments to the herders surveyed during the execution of this research.

\section{References :}

Adjagnissode S. G., 2003. Potentialités agro-sylvo-pastorales et possibilités d'accueil des éleveurs sahéliens dans trois communes de l'Alibori : Malanville - Kandi - Gogounou. Mémoire de DESS : Protection de l'environnement et amélioration des systèmes agraires.- Niamey (Université Abdou Moumouni).- 46 p.

Alkoiret T. I., Awohouédji D.Y. G., Akossou A.Y.J., Bosma R. 2009. Typologie des systèmes d'élevage bovin dans la Commune de Gogounou au 
nord-est du Bénin. Annale des sciences agronomiques du Bénin, (12) 2 : 7798.

Alkoiret T. I., Radji M., et Babatoundé. S. 2011. Typologie des élevages bovins installés dans la Commune de Ouaké au nord-ouest du Bénin, Livestock Research for Rural Development 23 (3).

Assani S.A., Alkoiret T.I. 2014. Typology of Gudali Cattle Farms Located in the Commons of Malancity And Karimama Extreme North of Benin, International Journal of Science and Advanced Technology, (4) 12: 1-5.

Bourzat D. 1986. Enquêtes et analyses multidimensionnelles : application à un cas concret de recherche-développement, Yatenga, Burkina-Faso, 15 p.

Capillon A. 1985. Connaître la diversité des exploitations : un préalable pour la recherche des références techniques régionales. Agriscope, 6 : 31-40.

Duval T., 2001. Lactating cattle of Philippines: creation of a typology of farming systems on the island of Mindanao. PhD Thesis, National Veterinary School of oulouse, France. 190 p.

Escofier B. and Pages J. 1990. Analyses factorielles simples et multiples. Objectifs, méthodes et interprétation, $2^{\mathrm{e}}$ édition, Paris, France, Bordas, 267 p. FAO. 2009. Database on Rural Income Generating Activities: Retrieved March 23, 2015, from: www.fao.org/fr/ESA/riga/french/index_en.htm.

FAO. 2015. FAO Statistics Data. Retrieved December 15, 2015, from http://faostat3.fao.org/site/browse/Q/QA/E,.

Houinato M. 2001. Phytosociologie, écologie, production et capacité de charge des formations végétales pâturées dans la région des monts Kouffé (Bénin). Thèse de doctorat, Université Libre de Bruxelles, Belgique, 255 p.

Houinato M. et Sinsin B. 2000. La pression agropastorale sur la zone riveraine de la réserve de biosphère de la Pendjari. Tropicultura, 18 (3) : pp 112-117.

Kiéma S. et Fournier A. 2007. Utilisation de trois aires protégées par l'élevage extensif dans l'Ouest du Burkina Faso. in A. FOURNIER, B. SINSIN, G.A. MENSAH (éd.). Quelles aires protégées pour l'Afrique de l'Ouest ? Conservation de la biodiversité et développement. Paris, Éditions IRD, La biodiversité et les hommes, collection Colloques et séminaires, p. 498-506.

Kpérou Gado B. 2006. Impacts socio-économiques de la transhumance transfrontalière dans la zone riveraine du parc $\mathrm{W}$ du Bénin. Diplôme de docteur vétérinaire, EIMSV-Dakar, 156p.

Lau H. D., J. F. Tourrand, B. Faye and J. B. Da Veiga, 2001. Typology of farming systems of the Amazon family farming: the case of the municipality of Uruará, Brazil. Journal of Animal Husbandry and Veterinary Medicine in Tropical Countries, 54 (3-4): 239-246. Retrieved August 23, 2015, from http://remvt.cirad.fr/revue/notice_fr.php?dk=509660 
Lesse P. 2011. Transhumance et Changements Climatiques : analyse de la gestion pastorale et de l'adaptation des éleveurs transhumants dans les communes riveraines de la Réserve de Biosphère Transfrontalière du W (Bénin). Faculté des Sciences Agronomiques, Université d’Abomey-Calavi (Bénin), 83p.

Lhoste P., V. Dollé, J. Rousseau and D. Soltner, 1993. Manual of Animal warm regions: breeding systems. Collection Manuals and Accurate breeding, Ministry of Cooperation, France, pp 281.

MAEP 2011. (Ministère d'Agriculture de l'Elevage et de la Pêche). Plan Stratégique de Relance du Secteur Agricole (PSRSA), Cotonou, République du Bénin, 112 p.

Perrot C., and Landais E. 1993. Comment modéliser la diversité des exploitations agricoles? Dossier: méthodes d'étude en milieu paysan. Cahier Recherche Développement, 33 : 24-40.

PGFTR (Programme de Gestion des Forêts et Terroirs Riverains) 2010. Plan d'aménagement de la forêt classée de l'Alibori Supérieur. DGFRN. 97p.

Roybin D. 1987. Typologies de fonctionnement d'exploitations : quelles applications pour le développement. GIS Alpes du Nord/SUACI Montagne Alpes du Nord/INRA SAD/CGER Haute-Savoie, France, 45 p.

Sawadogo I. 2011. Ressources fourragères et représentations des éleveurs, évolution des pratiques pastorales en contexte d'aire protégée : Cas du terroir de Kotchari à la périphérie de la réserve de biosphère du W au Burkina Faso, Thèse de doctorat, Museum National d'histoire naturelle, Paris, 336 p.

Sogbohossou E. A. 2000. L'élevage des bovins autour des aires protégées et son impact sur la faune sauvage et son habitat. Thèse Ingénieur Agronome. FSA. UNB. Abomey-Calavi, Bénin: 99 p.

Sounkéré K. 2003. Analyse des formes d'utilisation de l'espace dans les terroirs agropastoraux de la périphérie du parc national du $\mathrm{W}$ : cas de la commune de Karimama. Thèse pour l'obtention du diplôme d'ingénieur agronome FSA/UAC : 82p.

Sraïri M.T., 2004. Typology of dairy farming systems in Morocco in order to analyze their performance. PhD Thesis, Faculty of Agricultural Sciences, Gembloux, Belgium. 200 p.

Tache C., 2001. Cluster analysis of dairy farms in Réunion. Memory late ISTOM study, $80 \mathrm{p}$. 